\title{
SENSITIVITY OF MAMMALS TO CADMIUM NECROSIS OF THE TESTIS
}

\section{A. DUNCAN GHIQUOINE AND VALENTINA SUNTZEFF}

\author{
Department of Anatomy, Washington University, \\ St. Louis, Missouri, U.S.A.
}

\section{(Received 5th Fuly 1965)}

The testes of a variety of mammalian species have been reported to be sensitive to a subcutaneous or intraperitoneal injection of cadmium chloride at a dosage

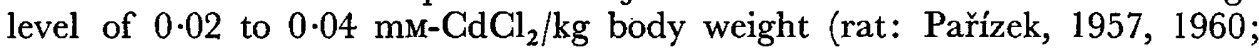
Mason, Brown, Young \& Nesbitt, 1964; Gunn, Gould \& Anderson, 1961; Kar \& Das, 1960; mouse: Meek, 1959; Chiquoine, 1964; rabbit: Pařízek, 1960; Cameron \& Foster, 1963; hamster: Pařízek, 1960; guinea-pig: Pařizek 1960) and the necrosis of the testis which follows such an injection has been described by these same authors. The rabbit, however, has been reported to be sensitive by Pařizek (1960) and by Cameron \& Foster (1963) but to be insensitive by Smith, Smith \& McCall (1960). Kar \& Das (1962) found no

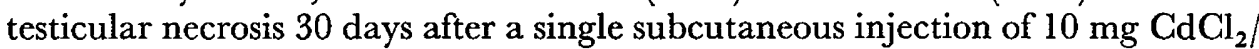
$\mathrm{kg}$ body weight but did observe the typical picture of cadmium necrosis 5 days after an intratesticular injection of $200 \mu \mathrm{g} / \mathrm{kg} \mathrm{CdCl}{ }_{2}$. These authors suggest that, following a subcutaneous injection of cadmium in their laboratory rabbits, the necessary critical concentration of cadmium within the testis was not attained, but that this concentration can be attained after an intratesticular injection. These observations suggest that there are differences in cadmium sensitivity between strains of rabbits. Chance observations in our own laboratory suggested differences in susceptibility to cadmium also between strains of mice.

Eight strains of mice were therefore tested for their sensitivity to subcutaneous injections of 0.02 to $0.04 \mathrm{~mm}-\mathrm{CdCl}_{2} / \mathrm{kg}$ body weight; not less than five mice of a given strain were tested in every case. Animals were injected with 0.075 to $0.1 \% \mathrm{CdCl}_{2} \cdot 2 \frac{1}{2} \mathrm{H}_{2} \mathrm{O}$ made up in distilled water at a dosage of $0 \cdot 1 \mathrm{ml} / 10 \mathrm{~g}$ body weight and killed 24 to $48 \mathrm{hr}$ later. Testes were examined grossly for signs of necrosis as well as microscopically in sections of Bouin's fixed tissue. With the exception of the 'Swiss albino' and 'Leaden' strains, which are maintained in our own colony, all the strains were obtained from the production stocks of the Jackson Laboratory, Bar Harbor, Maine.

Three of the strains $\left(\mathrm{C}_{3} \mathrm{H}, \mathrm{C} 57\right.$ and $\left.\mathrm{AJ}\right)$ were insensitive to subcutaneous injections of cadmium chloride while the other five (Swiss, Leaden, AKH, BALB, 129) showed the typical necrosis previously described in the mouse (Chiquoine, 1964). It would appear that no generalization concerning coat colour and cadmium sensitivity can be made since albino mice occur in both 
groups, i.e. Swiss, $\mathrm{AKH}$, and BALB are sensitive, while $\mathrm{AJ}$ is insensitive. Crosses of $\mathrm{C}_{3} \mathrm{H}$ (insensitive) mice with 'Albino' (sensitive) mice produced progeny with the typical $\mathrm{C}_{3} \mathrm{H}$ coat colour and all were sensitive to cadmium chloride administered as a subcutaneous injection. This was true regardless of the strain of the dam or sire.

On the other hand, all the strains of mice tested were sensitive to an intratesticular injection of $30 \mu \mathrm{g}$ of $\mathrm{CdCl}_{2} \cdot 2 \frac{1}{2} \mathrm{H}_{2} \mathrm{O}$ injected beneath the tunica albuginea. These observations, therefore, in the mouse are in agreement with the findings of Kar \& Das (1962) with respect to the rabbit and lend support to the suggestion that in some strains cadmium does not rise to a critical level within the testis when administered subcutaneously but that such strains will exhibit testicular necrosis when cadmium is administered directly into the organ.

It would appear that similar differences occur among guinea-pigs. In another experiment, all five albino guinea-pigs given the standard injection of 0.04 mM- $\mathrm{CdCl}_{2} / \mathrm{kg}$ body weight showed testicular necrosis but among five brown and white guinea-pigs, only two showed necrosis. Since the guinea-pigs were from a random bred colony no definite statement can be made as to strains, but the results demonstrate that not all guinea-pigs are susceptible to subcutaneous injections of cadmium salts.

In a previous study (Chiquoine, 1964) we reported that, with the exception of the opossum, all mammals possessing scrotal testes which had been tested to date were sensitive to cadmium administered subcutaneously. We have repeated the experiments with the opossum and find no signs of necrosis in the

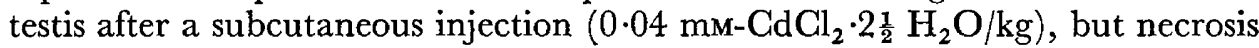
does occur following the intratesticular injection of $100 \mu \mathrm{g} \mathrm{CdCl}$. In a like manner we have studied the ferret and find this species similar to the opossum, i.e. insensitive to cadmium given subcutaneously but susceptible to cadmium given as an intratesticular injection.

Our work with the testis of the rooster (Chiquoine, 1964) has been confirmed by Erickson \& Pincus (1964) who also report no testicular necrosis following a subcutaneous injection of cadmium chloride. However, Guthrie's (1964) work on the fowl testis suggests that intratesticular injections are effective.

Paŕizek (1965) has recently reported that the pregnant rat is also sensitive to cadmium and that a single subcutaneous injection results in foetal death and resorption. We have confirmed this reaction in the pregnant mouse (Chiquoine, 1965). On the other hand, MacKawa \& Hosoyama (1965) failed to find any such effect of cadmium on the pregnant rats in their laboratory. This discrepancy may well be another instance of differences in susceptibility of animal strains to subcutaneous or intraperitoneal injections of cadmium.

In summary, this note documents the fact that the sensitivity of the testis of various species to a subcutaneous injection of cadmium salts depends upon the genotype of the animal but that the testes of all species examined are sensitive to intratesticular injections.

This research was supported by Grant HD-01050-01 from the National Institute of Child Health and Human Development. 


\section{REFERENCES}

CAmeron, E. \& Foster, C. L. (1963) Observations on the histological effects of sub-lethal doses of cadmium chloride in the rabbit. I. The effect on the testis. F. Anat. 97, 269.

Chrouorne, A. D. (1964) Observations on the early events of cadmium necrosis of the testis. Anat. Rec. $149,23$.

Chrovorne, A. D. (1965) The effect of cadmium chloride on the pregnant albino mouse. F. Reprod. Fertil. 10, 263.

Erickson, A. E. \& Pincus, G. (1964) Insensitivity of fowl testis to cadmium. 7. Reprod. Fertil. 7, 379.

Gunn, S. A., Gould, T. G. \& ANDERson, W. A. (1961) Zinc protection against cadmium injury to rat testis. Archs. Path. 71, 274.

Guthrie, J. (1964) Histological effects of intra-testicular injections of cadmium chloride in domestic fowl. Br. J. Cancer 18, 255.

KAR, A. B. \& DAS, R. P. (1960) Testicular changes in rats after treatment with cadmium chloride Acta biol. med. germ. 5, 153.

KAR, A. B. \& DAs, R. P. (1962) Sterilization of males by intratesticular administration of cadmium chloride. Acta Endocr. Copenh. 40, 321.

MAcKaWA, K. \& Hosoyama, Y. (1965) Morphological and functional sex-differentiation in rats born to cadmium-injected mothers. Zool. Mag. 74, 24. (Japanese with English summary).

Mason, K. E., Brown, J. A., Young, J. O. \& Nesbit, R. R. (1964) Cadmium induced injury of the rat testis. Anat. Rec. 149, 135.

MEEk, E. S. (1959) Cellular changes induced by cadmium in mouse testis and liver. Brit. F. exp. Path. 40, 503.

Paḱízek, J. (1957) The destructive effect of cadmium ion on testicular tissue and its prevention by zinc. F. Endocr. 15, 56.

PAŘizex, J. (1960) Sterilization of the male by cadmium salts. F. Reprod. Fertil. 1, 294.

PAŘízeK, J. (1965) Vascular changes at sites of oestrogen biosynthesis produced by parenteral injections of cadmium salts. $\mathcal{F}$. Reprod. Fertil. 7, 263.

Sмтth, J. P., Smtth, J. C. \& MaCall, A. J. (1960) chronic poisoning from cadmium fume. f. Path. Bact. 80, 287. 